Al-Fikra: Jurnal Ilmiah Keislaman, Vol. 3, No. 2, Juli-Desember 2004

\title{
PELEMBAGAAN HISBAH DI INDONESIA
}

\section{Akhmad Mujabidin}

\begin{abstract}
There is an inclination that the conscience of the Muslims more and more increase to apply their religious teachings for attaining spiritual and material needs. The conscience of studying Islamic teachings for implementation cannot be apart from the role of Islamic dakwah institutions. It cannot be denied that Islamic law is an un-separated sub-system of national legal system. It can be proved by institutionalization of Islamic law even though only in terms of family law, bequest, and donated property, and moreover the alms and pilgrimage institutions are recently founded. These legal products may be main indicator that prospect of Islamic law institutionalization including hisbah in Indonesia will be better, brighter, and more increasing in the future.
\end{abstract}

Keywords: Islamic law, hisbah, and institutionalization

$$
\begin{aligned}
& \text { الملخص: هناك ميول إلى ازدياد وعى المسلمين يوما بعد يوم للإقامة بتعاليم دينهم قصدا } \\
& \text { لقضاء حاجاهم الروحية و كما يقصد أيضا لتوفير حاجاتم المادية. و أن الوعى لدراسة } \\
& \text { تعاليم الإسلام لتطبيقها لا يستغنى عن دور معاهد الدعوة الإسلامية . و أنه لا يمكن أن } \\
& \text { يرفض أن الشريعة الإسلامية هى العنصر الذى لا يمكن الفرق بينه و بين نظام القانون و } \\
& \text { الحقوق القومى. و هذا يتبين من تأسيس معاهد الحلكم و القضاء الإسلامى و إن كانت } \\
& \text { محدودة في العدد كمثل أحكام المعاملة و المناكحات و الفراءض و الأوقاف و كما أسست } \\
& \text { أيضا في هذا العصر الأخير المعاهد لشئون الزكاة و الحج. و يمكن أن يجعل هذه الإنتاجات } \\
& \text { القانونية كالدليل على أن مستقبل تمعهد الشريعة الإسلامية ، منها معهد الحسبة ، بإندونيسيا } \\
& \text { متطور ساطع متزايد. }
\end{aligned}
$$

\section{Pendahuluan}

Dewasa ini terdapat kecenderungan semakin meningkatnya kesadaran kaum muslimin dalam menjalankan agamanya sebagai pemenuhan kebutuhan spiritual di satu pihak, dan dalam usahanya untuk memenuhi kebutuhan hidup ${ }^{1}$ di pihak lain, terutama dalam kegiatan usaha di bidang ekonomi. Pemuasan kebutuhan materi menghendaki pembangunan umat manusia dan sumbersumber daya materi dalam suatu pola yang merata sehingga semua kebutuhan manusia dapat dipenuhi secara utuh dan terwujud suatu distribusi pendapatan 
dan kekayaan yang adil.

Munculnya kesadaran umat Islam dalam mengkaji ajaran Islam untuk diterapkan dalam kehidupan sehari-hari, tidak terlepas dari peran lembagalembaga dakwah Islam, majelis-majelis taklim dan kelompok-kelompok pengajian baik yang berada di kampus, perusahaan, maupun di tengah-tengah masyarakat. ${ }^{2}$ Semakin maraknya kemunculan lembaga-lembaga seperti ini, pada akhirnya akan dapat mengambil prakarsa untuk mengajarkan dan mengajak umat Islam untuk meningkatkan kegiatan muamalatnya sebagai bagian yang tidak terpisahkan dari ibadah mereka kepada Allah swt. Sebagai contoh, saat ini kaum muslimin telah mempunyai pilihan dalam menjalankan kegiatan di bidang keuangan. Jika sebelumnya hanya dikenal bank-bank umum dan asuransi yang terlepas dari kaidah-kaidah ajaran Islam, maka sejak lahirnya Bank Muamalat Indonesia, BPR Syari'ah, dan Asuransi Takaful, umat Islam dapat menjalankan kegiatan usahanya yang tidak hanya berdimensi duniawi tetapi juga berdimensi ukhrawi.

\section{Sejarah Pelembagaan Hukum Islam di Indonesia}

Hukum Islam merupakan kumpulan dari aturan Allah dan Rasul-Nya yang mengatur kehidupan seluruh umat manusia sesuai dengan misi Islam sebagai agama universal (rahmatan li al-'alamin). Hal ini menunjukkan bahwa hukum Islam tidak hanya berlaku bagi orang Islam, tetapi juga bagi orangorang non-Islam sekalipun. Oleh karena itu, dengan karakteristik universal ini, maka hukum Islam menempati posisi yang penting dan strategis dalam prespektif umat Islam. ${ }^{3}$ Hal ini menunjukkan bahwa sangat mustahil orang bisa memahami Islam tanpa memahami hukum Islam. Dalam kasus Indonesia, sejak Islam masuk ke nusantara ${ }^{4}$ dan menjadi agama rakyat Melayu, hukum Islam sudah memainkan peranan penting dalam kehidupan rakyat Indonesia. Hal ini bisa dilihat dalam periode kerajaan Islam awal ${ }^{5}$ bahkan hukum Islam dijadikan sebagai hukum resmi kerajaan seiring dengan ditetapkannya Islam sebagai agama resmi kerajaan. ${ }^{6}$ Kondisi seperti ini dapat kita lihat dan rasakan bahwa hukum Islam sampai sekarang dapat berperan aktif dalam tatanan kehidupan bermasyarakat dan bernegara yang berlaku baik secara normatif maupun yuridis formal di Indonesia.

Indonesia adalah negara hukum yang sejak berdirinya sudah berkeinginan membentuk hukum nasionalnya sendiri. Sorotan banyak muncul ketika pemerintah mengeluarkan Undang-undang No. 1 tahun 1946 yang isinya memberlakukan Undang-Undang Hukum Pidana Hindia Belanda. ${ }^{7}$ Apa yang dilakukan pemerintah saat itu merupakan hal yang wajar karena umur negara Indonesia yang masih berada dalam hitungan bulan dan kesibukan pemerintah dalam berbagai hal untuk mempertahankan kemerdekaan, maka upaya menerbitkan undang-undang tersebut dapat dipahami sebagai pengisi kekosongan hukum. 
Perkembangan selanjutnya menunjukkan bahwa dalam rangka pembinaan hukum nasional, hukum Islam merupakan aset penting yang sangat berharga karena selain mayoritas penduduk Indonesia beragama Islam juga karena hukum Islam merupakan sub-sistem hukum nasional Indonesia berdampingan dengan hukum Adat dan hukum Barat sejak Dekrit Presiden 5 Juli 1959.8 Dalam kaitan inilah, kajian tentang kelembagaan hukum Islam di Indonesia, termasuk upaya melembagakan $h\{i s b a h$, sangat penting dilakukan dengan pertimbangan bahwa pada saat ini upaya serius yang dilakukan di negara-negara berpenduduk muslim, tak terkecuali Indonesia, adalah selain mengejar ketertinggalan dalam bidang ilmu pengetahuan dan teknologi, juga secara bertahap memperbarui hukum, yang sebagiannya masih merupakan peninggalan kolonial. Dalam upaya ini, para pakar, akademisi, dan praktisi hukum Islam dituntut untuk memberikan solusi agar tercipta hukum nasional yang bisa mengayomi segenap lapisan masyarakat.

Kedudukan hukum Islam dalam negara Republik Indonesia secara eksplisit tercantum dalam pasal 29 UUD 1945 yang menyatakan bahwa negara berdasarkan atas Ketuhanan Yang Maha Esa dan menjamin kemerdekaan masing-masing penduduk untuk melaksanakan ibadah berdasarkan agama dan kepercayaannya. ${ }^{9}$ Menurut Hazairin, kaidah fundamental dalam pasal tersebut dapat ditafsirkan sebagai berikut:

1. Dalam negara RI tidak boleh ada atau tidak boleh berlaku hukum yang bertentangan dengan kaidah-kaidah agama yang berlaku bagi pemeluk agama.

2. Negara wajib menjalankan syariat semua agama yang berlaku di Indonesia, kalau untuk menjalankan shariah itu memerlukan bantuan kekuasaan negara. ${ }^{10}$

Shari'ab yang tidak memerlukan kekuasaan negara untuk melaksanakannya karena dapat dijalankan sendiri oleh setiap pemeluk agama yang bersangkutan seperti salat dan puasa bagi umat Islam, menjadi kewajiban pribadi pemeluk agama itu sendiri untuk menjalankannya menurut ketentuan agamanya masing-masing.

Pasal 29 UUD 1945 ini mempunyai tiga muatan makna. Pertama, negara tidak boleh membuat peraturan perundang-undangan atau melakukan kebijakan-kebijakan yang bertentangan dengan dasar keimanan kepada Tuhan Yang Maha Esa. Kedua, negara berkewajiban membuat peraturan perundangundangan atau melakukan kebijakan-kebijakan bagi pelaksanaan wujud rasa keimanan kepada Tuhan Yang Maha Esa dari segolongan pemeluk agama yang memerlukannya. Ketiga, negara berkewajiban membuat peraturan perundangundangan yang melarang siapa pun melakukan pelecehan terhadap ajaran agama. $^{11}$

Dengan tiga makna ini dapat dipahami bahwa negara berkewajiban 
secara aktif melakukan upaya-upaya agar setiap penduduk dapat memeluk agama dan beribadat menurut agama dan kepercayaannya itu. Keaktifan negara di sini adalah untuk menjamin agar setiap penduduk dapat merdeka menentukan pilihan atas agama yang hendak dipeluknya dan jaminan agar setiap penduduk dapat menjalankan ibadahnya menurut agama dan kepercayaan yang ditetapkan oleh agama yang dipeluknya. Tetapi keaktifan negara tidak boleh mencampuri aturan-aturan internal ${ }^{12}$ yang telah ditentukan oleh masing-masing agama penduduknya.

Bagi umat Islam, pelaksanaan isi pasal 29 tersebut telah terwujud dalam bentuk UU No. 1 tahun 1974 tentang Perkawinan, UU No. 7 tahun 1989 tentang Peradilan Agama, Inpres No. 1 tahun 1991 tentang Kompilasi Hukum Islam, dan UU No. 7 tahun 1992 tentang Perbankan. UU No. 17 tahun 1999 tentang Penyelenggaraan Ibadah Haji, UU No. 38 tahun 1999 Pengelolaan Zakat, UU. No 44 tahun 1999 tentang Penyelenggaraan Keistimewaan Provinsi DI Aceh, UU. No. 18 tahun 2001 tentang Otonomi Khusus Provinsi DI Aceh sebagai Provinsi Nangroe Aceh Darussalam. ${ }^{13}$

Realitas ini menunjukkan bahwa negara Indonesia telah memberikan ruang gerak yang cukup bagi terlembaganya hukum Islam dalam sistem hukum nasional. Dengan demikian setiap muslim dapat sepenuhnya menjalankan kegiatan sesuai dengan ajaran-ajaran Islam apabila mereka menghendaki. Jika dielaborasi lebih lanjut maka dalam kegiatan di bidang muamalat seperti jualbeli, sewa-menyewa, dan lain-lain juga dapat dilakukan sepenuhnya berdasarkan hukum Islam, sehingga seluruh kegiatan dalam kehidupan muslim akan tunduk kepada hukum Islam. Logikanya apabila dalam bidang perkawinan, kewarisan, dan wakaf sudah ada Kompilasi Hukum Islam, mengapa dalam bidang muamalat seperti jual-beli belum ada Kompilasi Hukum Islam di bidang muamalat. Keberadaan kompilasi hukum di bidang muamalat ini dirasakan sangat mendesak untuk segera diwujudkan ${ }^{14}$ karena ekonomi merupakan salah satu bidang yang sangat menentukan kualitas hidup umat muslim.

Negara Indonesia yang berfalsafah Pancasila melindungi agama, penganut agama, bahkan berusaha memasukkan ajaran dan hukum agama Islam dalam kehidupan berbangsa dan bernegara. Mohammad Hatta (wakil Presiden RI I) menyatakan bahwa dalam pengaturan negara hukum Republik Indonesia, shariah Islam berdasarkan al-Qur'an dan Hadith dapat dijadikan peraturan perundang-undangan Indonesia sehingga orang Islam mempunyai sistem shariah yang sesuai dengan kondisi Indonesia. ${ }^{15} \mathrm{Hal}$ ini menunjukkan bahwa Hukum Islam mempunyai peluang yang besar untuk diberlakukan dalam sistem hukum nasional, karena Indonesia adalah negara yang berdasarkan atas hukum (rechtsstaat), tidak berdasarkan atas kekuasaan belaka (machtsstaat) ${ }^{16}$ Sumber dari segala sumber hukum nasional adalah Pancasila, karena itu berlaku pula hukum agama dan toleransi antar umat beragama 
dalam bermasyarakat, berbangsa, dan bernegara. ${ }^{17}$

Indikasi bahwa Hukum Islam di Indonesia dapat diakomodir dalam sistem hukum nasional dapat dilihat dari fakta-fakta berikut ini:

1. Undang-undang yang sudah ada dan berlaku saat ini, seperti UU Perkawinan, UU Peradilan Agama, dan lain-lain merupakan modal bagi terbentuknya undang-undang lainnya.

2. Jumlah penduduk Indonesia yang mencapai lebih kurang $95 \%$ beragama Islam akan memberikan pertimbangan yang sangat signifikan dalam mengakomodasi kepentingannya. Demi terselenggaranya pelaksanaan hukum yang lebih efektif dan efisien, maka solusi yang tepat adalah memenuhi aspirasi mayoritas penduduk Indonesia yang beragama Islam ini.

3. Kesadaran umat Islam dalam praktek sehari-hari. Banyak aktifitas keagamaan masyarakat selama ini yang merupakan cerminan dari kesadaran mereka menjalankan shariah atau Hukum Islam seperti pembagian zakat dan waris.

4. Politik pemerintah atau political will dari pemerintah dalam hal ini sangat dibutuhkan. Tanpa adanya kemauan politik dari pemerintah, mustahil Hukum Islam dapat menjadi bagian dari tata hukum di Indonesia. ${ }^{18}$

Dengan melihat indikator-indikator tersebut, maka diperlukan keterlibatan para akademisi perguruan tinggi, baik di fakultas hukum maupun fakultas syari'ah agar dapat mengembangkan penelitian yang pada akhirnya dapat dijadikan pedoman bagi praktisi hukum dalam mengambil keputusan yang terkait dengan persoalan hukum yang hidup dan terjadi di dalam masyarakat.

\section{Peluang Pelembagaan Hisbah}

Untuk melihat peluang pelembagaan hisbah harus mengetahui kekuatankekuatan yang akan mengantarkan hukum Islam sampai tahapan yang dikendaki yaitu terlembaganya hukum Islam sebagai hukum positif di Indonesia. Hal ini disebabkan karena hal-hal lain yang akan menghambat proses pelembagaan itu harus harus diantisipasi, seperti kendala-kendala, kelemahan-kelemahan, dan tantangan-tantangan. Oleh karena itu, analisis tentang peluang pelembagaan hukum Islam, khususnya tentang hisbah, dilakukan dengan menggunakan analisis SWOT yang merupakan singkatan dari strengths (kekuatan), weaknesses (kelemahan), opportunities (peluang), dan threats (ancaman). ${ }^{19}$ Analisis ini didasarkan pada logika yang dapat memaksimalkan kekuatan sehingga menemukan peluang, namun pada saat yang bersamaan dapat meminimalkan kelemahan dan mengatasi ancaman. Dengan analisis ini, keputusan yang akan diambil telah melalui kajian yang 
matang dan mendalam.

Aspek kekuatan hukum Islam terletak pada dua sumber utamanya yaitu al-Qur'an dan Hadith, yang selain memuat ajaran tentang akidah dan akhlak juga memuat aturan hukum kemasyarakatan, baik perdata maupun pidana. ${ }^{20}$ Ketiga bidang ajaran tersebut merupakan satu kesatuan yang saling mendukung. Dari ketiga bidang ini lahirlah prinsip, asas, dan tujuan hukum Islam. ${ }^{21}$ Tujuan hukum Islam adalah untuk menciptakan kemaslahatan manusia sesuai dengan kodrat dan fitrahnya. Oleh karena itu, dalam hukum Islam kebajikan diperintahkan dan kemunkaran dilarang. ${ }^{22}$

Dalam konteks Indonesia, eksistensi hukum Islam masih berada dalam perjuangan. Artinya, dahulu, kini, dan akan datang, hukum Islam ada di dalam hukum nasional, baik yang tertulis maupun konvensional, dalam berbagai aspek kehidupan dan praktek hukum. Beberapa kekuatan yang dapat disebutkan di sini adalah:

a. Mayoritas rakyat Indonesia adalah beragama Islam. Ini merupakan modal pertama dan utama bagi pembangunan dan pengembangan hukum Islam. ${ }^{23}$ Modal ini harus pula dijadikan piranti yang mendapatkan perhatian lebih dalam rangka pembentukan sistem hukum nasional serta pembangunan dan pengembangannya.

b. Negara Kesatuan Republik Indonesia adalah negara yang berdasarkan atas hukum. Sementara itu, kedudukan agama dalam negara ini sangat kuat, karena negara adalah negaranya orang yang beragama, bahkan ada yang mengatakan bahwa Indonesia adalah negaranya orang Islam, bukan negara sekuler. Nilai-nilai agama sangat kental dalam kehidupan rakyatnya. Oleh karena itu, agama secara normatif diharapkan mampu memberikan kontribusi yang sangat berharga

c. terhadap hukum nasional. Dalam hal ini, agama akan diposisikan sebagai filter perundang-undangan yang akan diberlakukan di negara kita. ${ }^{24}$

d. Pembangunan di bidang hukum, sebagaimana tertuang dalam GBHN menghendaki terciptanya hukum baru bagi Indonesia yang sesuai dengan watak dan kepribadian bangsa Indonesia serta dengan cita-cita hukum Pancasila dan UUD 1945. Dalam hal ini, hukum nasional yang dikehendaki adalah yang mampu menampung dan memasukkan hukum agama serta tidak memuat norma hukum yang bertentangan dengan hukum agama, khususnya agama Islam. ${ }^{25}$

e. Dewasa ini, umat Islam telah memiliki badan peradilan sendiri. Hal itu diharapkan mampu menata kehidupan yang tenteram dan damai serta dapat berperan aktif dalam menciptakan kekuasaan yudikatif atau kehakiman yang handal dan berwibawa, sebagaimana yang diharapkan oleh seluruh rakyat Indonesia. ${ }^{26}$ 
f. Eksistensi lembaga pendidikan yang berbasis keagamaan seperti pesantren, madrasah, IAIN/STAIN, serta PTAIS dengan Fakultas Syari'ah di dalamnya yang secara intensif mengadakan pengkajian terhadap hukum Islam bisa diharapkan mampu memberikan masukan terhadap mutu hukum Islam.

Kondisi ini membuktikan bahwa hukum Islam mempunyai kekuatan dan kemampuan dalam berintegrasi dengan hukum nasional. Kekuatan ini akan semakin kokoh karena didukung oleh Pancasila dan UUD 1945. Pancasila, yang sila-silanya merupakan norma dasar atau norma tertinggi bagi berlakunya semua norma hukum, telah mendudukkan agama pada posisi yang sangat fundamental, serta memasukkan ajaran agama dan hukumnya dalam kehidupan berbangsa dan bernegara. Kondisi ini juga menggambarkan bahwa berlaku efektifnya hukum Islam merupakan sesuatu yang sangat didambakan dan diperlukan oleh masyarakat Islam Indonesia, sebagai mayoritas penduduk negeri ini.

Dengan demikian, bila kita mencermati dengan seksama dan teliti kekuatan-kekuatan hukum Islam di atas, maka kita harus yakin dan opitimis bahwa pelembagaan hukum Islam yang merupakan bagian dari ajaran agama yang dianut oleh mayoritas penduduk Indonesia, memiliki peluang besar untuk dijadikan hukum nasional Indonesia, termasuk di dalamnya pelembagaan h\{isbah dalam sistem hukum nasional.

Hal yang perlu disadari adalah bahwa dalam menempuh jalur pelembagaan ini, hukum Islam akan mengalami banyak kendala, baik yang bersifat internal maupun eksternal. Di antara kendala internal adalah terbatasnya personil hukum Islam dalam lembaga-lembaga penentu kebijakan hukum nasional dan terbatasnya sumber daya dan dana untuk melakukan kajian terhadap hukum Islam. Sedangkan kendala eksternal adalah masih berlakunya sebagian produk hukum kolonial, adanya image negatif terhadap hukum Islam, trauma masa lampau di beberapa daerah dalam praktek pemberlakuan hukum Islam, dan beragamnya budaya masyarakat. Kendala lainnya adalah masih dianutnya kebijakan politik hukum kolonial. Kebijaksanaan ini akan berimplikasi pada kemandirian Peradilan Agama yang tidak sepenuhnya bisa mengurus urusannya sendiri dan masih terkesan subordinatif pada peradilan umum.

Selain itu, terdapat pula kendala legislasi, seperti kendala kultural dan historis. Adanya trikhotomi hukum (Islam, Adat, dan Barat) selalu melahirkan kontroversi dan kegoncangan politik yang dapat mengganggu stabilitas nasional yang selalu mengancam persatuan dan kesatuan bangsa. Kontroversi terjadi karena tidak semua orang yang duduk di badan legislatif mendukung diberlakukannya hukum Islam. Bahkan hukum Islam selalu diidentifikasikan dalam posisi yang berlawanan dengan hukum Adat dan Barat. ${ }^{27}$ Apabila kondisi ini tidak teratasi maka besar kemungkinan hukum Islam akan 
mengalami pergeseran dan menempati posisi marginal dalam sistem hukum nasional.

Dengan melihat kendala-kendala tersebut, maka kita ditantang untuk mengadakan perbaikan dalam sistem hukum Islam. Kelemahan yang ada pada diri umat Islam saat ini adalah masih lemahnya pemahaman dan orientasi hukum di kalangan masyarakat yang ditambah lagi dengan belum adanya kesiapan dari para tokoh agama untuk menerima pembaruan di segala bidang, termasuk hukum Islam. Oleh karena itu, pembaharuan hukum Islam merupakan keniscayaan yang harus dilakukan saat ini.

Pembaruan hukum Islam diupayakan dalam kerangka pembangunan nasional yang menyangkut dua hal yaitu materi hukum dan aparatur hukum, dan sarana dan prasarana hukum. Pemerintah harus selalu menggariskan upaya-upaya yang harus dikerjakan dalam rangka pembinaan dan pembangunan hukum nasional. Dari adanya upaya-upaya tersebut diharapkan akan mampu menyelesaikan, atau paling tidak mencarikan solusi, konflik hukum yang masih terjerat dalam perangkap trikhotomi hukum. Dalam hal ini upaya-upaya tersebut diperkirakan tidak akan berhasil kalau digarap secara tambal sulam. Dengan kata lain, keberhasilan upaya-upaya tersebut akan tampak dan terasa jika diproses dan direformasi dengan konsep-konsep yang integral berdasarkan Pancasila dan UUD 1945. ${ }^{28}$

Dalam rangka menghapus hukum kolonial dan menggantikannya dengan hukum yang sesuai dengan watak dan kepribadian bangsa Indonesia, tampaknya hukum Islam cukup mampu untuk berperan di dalamnya. Hukum Islam sebagai sub-sistem dari sistem hukum nasional dirasa perlu juga mengadakan pembaruan. Pembaruan hukum Islam ini akan mampu memberikan sumbangan yang berarti terlaksananya pembaruan hukum nasional. Hal tersebut tidak terlepas dari posisi hukum Islam yang telah diakui sebagai salah satu sumber bagi pembaruan hukum di Indonesia, selain hukum Adat dan Barat.

Tantangan yang dihadapi hukum Islam saat ini adalah Pertama, tantangan yang datang dari masyarakat informasi. Kemajuan teknologi, khususnya di bidang telekomikasi dan informatika, telah menyebabkan dunia berada dalam peradaban global. Arus globalisasi yang diperkirakan akan berperan juga dalam meniupkan paham sekularisme, kapitalisme-materialisme, dan kolonialisme akan melanda negara-negara berkembang, seperti Indonesia. Kondisi seperti ini, secara langsung atau tidak, akan berpengaruh pada kualitas keberagamaan masyarakat yang dilanda arus tersebut. Kedua, tantangan yang muncul dari dalam sendiri yaitu berkenaan dengan eksistensi hukum Islam dalam hukum nasional. Meskipun hukum Islam telah diakui sebagai salah satu unsur pembentukan hukum nasional, akan tetapi hukum tersebut, menurut Zarkowi Soejoeti, masih memerlukan pengkajian yang lebih mendalam, supaya mampu menjawab tantangan zaman, apalagi hukum positif sudah berkembang 
pesat. $^{29}$

Dengan demikian, kualitas hukum Islam harus lebih ditingkatkan agar mampu bersaing dengan berbagai sistem hukum yang ada. Untuk memulainya, maka pembaruan hukum dimulai dengan pembaruan orientasi berfikir para ahli hukum dan kesadaran hukum masyarakat yang masih bersifat dualistis antara keahlian hukum agama dan hukum umum. Setelah itu baru dilakukan restrukturisasi kelembagaan. Tetapi Soejoeti menyatakan bahwa pembaruan hukum Islam bukan terletak pada institusi yang mengurus hukum Islam, melainkan pada intensitas pengkajian hukum Islam itu sendiri. ${ }^{30}$

Penulis berkeyakinan bahwa pembaruan hukum Islam meliputi pembaruan orientasi berfikir dan institusi. Keduanya saling mengisi. Pembaruan orientasi berfikir dilakukan dalam rangka mengisi institusi, sedangkan pembaruan institusi dilakukan dalam rangka menampung aspirasi orientasi berfikir seiring dengan laju perkembangannya.

Kekuatan akan melahirkan peluang, namun pada saat yang bersamaan akan muncul kelemahan dan ancaman. Kelemahan dan ancaman pelembagaan hukum Islam di Indonesia dapat dilihat pada hal-hal sebagai berikut:

a. Kemajemukan Indonesia yang tercermin dalam kemajemukan masyarakat Islam Indonesia, baik etnis, budaya, dan lainnya. Akibatnya, tidak semua masalah hukum bisa diunifikasi, melainkan harus dipilah, mana hukum Islam yang bisa diunifikasi dan mana yang belum.

b. Keberatan masyarakat non-muslim atas pemberlakuan hukum Islam pada hukum nasional. Dampaknya secara politis belum pernah terjadi adanya political will yang kuat dari penguasa untuk memberlakukan hukum Islam, apalagi di bidang pidana.

c. Lemahnya kesadaran masyarakat Islam sendiri terhadap pemberlakuan hukum Islam, yang kemudian difasilitasi oleh adanya opsi bagi umat Islam, seperti kasus sengketa waris, untuk memilih Pengadilan Agama atau Pengadilan Umum dalam penyelesaian sengketa mereka.

d. Lemahnya pemahaman dan penguasaan umat Islam terhadap hukum agamanya sendiri. Ironisnya, kondisi ini terjadi pula di kalangan cendekiawan muslim sendiri, baik karena lemahnya penguasaan bahasa, metode istinbat, maupun karena sebab lain.

Analisis mendalam terhadap peluang pelembagaan hisbah mengharuskan kita untuk melihat prospek pelembagaan hukum Islam di Indonesia yang dimulai dengan mengakaji aspirasi umat Islam di berbagai daerah untuk memberlakukan hukum Islam. Di Sumatera Barat muncul keinginan kuat untuk legislasi perda yang bernuansakan Islam. Salah satunya tercermin dalam Rancangan Peraturan Daerah (Raperda) yang dimaksudkan untuk memberantas kemaksiatan di wilayah tersebut. Dalam salah satu klausulnya, 
raperda itu melarang media massa mengekspos atau menyebarluaskan hal-hal yang berkaitan dengan kemaksiatan (pornografi). ${ }^{31}$ Di Tasikmalaya sudah dikeluarkan Perda No. 1 tahun 2000 yang mengancam siapa saja yang menawarkan atau menyediakan diri, menyediakan tempat, atau melindungi perbuatan yang tergolong pelacuran dengan ancaman denda maksimal lima juta rupiah atau kurungan paling lama tiga bulan. ${ }^{32}$ Di Cianjur juga telah dikeluarkan Perda No. 22 tahun 2000. Dalam perda ini, orang yang melacurkan diri, memperdagangkan, atau menyediakan fasilitas akan dikenai sanksi kurungan tiga bulan serta denda tiga juta rupiah. ${ }^{33}$

Di Sulawesi Selatan masyarakat yang dimotori oleh Komite Penegakan Penerapan Syari'at Islam (KPPPSI) menuntut penerapan shariah Islam melalui otonomi khusus. ${ }^{34}$ Aspirasi yang sama juga terjadi di Kalimantan Selatan pada saat Musyawarah Besar Pembangunan Banua Banjar (MBPBB) di Banjarmasin tanggal 13-15 Agustus 2000 yang diikuti masyarakat Banjar dari dalam dan luar negeri. Keputusan musyawarah ini adalah menuntut pemerintah untuk melaksanakan shari'ah Islam. ${ }^{35}$

Beberapa fenomena tersebut menunjukkan bahwa telah hidup aspirasi penegakan shariah Islam di berbagai aspek kehidupan, walaupun cakupan dan materi yang diperjuangkan itu berbeda-beda sesuai dengan faktor historis, yuridis, sosiologis, dan konfigurasi politik di masing-masing daerah. Aceh misalnya, menempati cakupan yang paling luas di banding daerah lain, sesuai dengan keistimewaan daerah yang dilandasai undang-undang tentang keistimewaan Aceh dan undang-undang otonomi khusus sebagai provinsi Nanggroe Aceh Darussalam.

Pada bagian ini, disoroti beberapa pasal dari UU No. 18 Tahun 2001 tentang Otonomi Khusus Provinsi Daerah Istimewa Aceh sebagai Provinsi Nanggroe Aceh Darussalam ${ }^{36}$ yang berkaitan dengan penegakan shariah Islam yang lebih luas, artinya bukan hanya hukum keluarga tetapi juga hukum publik.

Beberapa pasal UU No. 18 tahun 2001 menunjukkan bahwa penerapan shari'ah Islam dilakukan secara bertahap, antara lain:

1. Pasal 1 ayat 7 menyatakan bahwa Mahkamah Syar'iyyah Provinsi Nanggroe Aceh Darussalam adalah lembaga peradilan yang bebas dari pengaruh pihak manapun dalam wilayah Provinsi Nanggroe Aceh Darussalam yang berlaku untuk pemeluk agama Islam.

2. Pasal 1 ayat 8 menyatakan bahwa qanun Provinsi Nanggroe Aceh Darussalam adalah peraturan daerah sebagai pelaksanaan undang-undang di wilayah Nanggroe Aceh Darussalam dalam rangka penyelenggaraan otonomi khusus.

3. Pasal 9 ayat 1 yang menyatakan bahwa kekuasaan legislatif di Provinsi Nanggroe Aceh Darussalam dilaksanakan oleh Dewan Perwakilan Rakyat Daerah Provinsi Nanggroe Aceh Darussalam. 
Al-Fikra: Jurnal Ilmiah Keislaman, Vol. 3, No. 2, Juli-Desember 2004

4. Pasal 9 ayat 2 menyatakan bahwa Dewan Perwakilan Rakyat Daerah Provinsi Nanggroe Aceh Darussalam mempunyai fungsi legislasi, penganggaran, dan pengawasan kebijakan daerah.

5. Pasal 11 ayat 1 menyatakan bahwa Dewan Perwakilan Rakyat Daerah Provinsi Nanggroe Aceh Darussalam sebagai lembaga perwakilan merupakan wahana untuk melaksanakan demokrasi yang menjunjung tinggi nilai-nilai shari'ah Islam.

Pemberlakuan hukum-hukum berdasarkan nilai-nilai shariah Islam harus didukung oleh lembaga peradilan khusus syari'at Islam. Mengenai hal ini UU No. 18 tahun 2001 menyatakan:

Pasal 25:

1. Pengadilan Syari'at Islam di Provinsi Nanggroe Aceh Darussalam sebagai bagian dari sistem peradilan nasional dilakukan oleh Mahkamah Syar'iyyah yang bebas dari pengaruh pihak manapun.

2. Kewenangan Mahkamah Syar'iyyah sebagaimana dimaksud pada ayat 1 didasarkan atas syari'at Islam dalam sistem hukum nasional, yang diatur lebih lanjut dengan Qanun Provinsi Nanggroe Aceh Darussalam.

3. Kewenangan sebagaimana dimaksud pada ayat 2 diberlakukan bagi pemeluk agama Islam.

Dengan demikian UU No. 18 tahun 2001 merupakan pintu gerbang untuk memasuki kondisi baru penegakan shariah Islam di Indonesia, khususnya di Aceh. Dalam UU ini memang belum diatur secara rinci ketentuan hukum yang didasarkan pada shariah Islam, misalnya di bidang pidana, namun pada saatnya nanti akan dibuat dalam bentuk qanun yang di dalamnya akan dirumuskan ketentuan-ketentuan terperinci. Dengan melihat kasus Aceh ini, maka penerapan dan pelembagaan hukum Islam di Indonesia dimulai dari daerah-daerah. Dari sini ada prospek yang cerah bagi pelembagaan hukum Islam secara nasional.

Setelah mengkaji kekuatan, kelemahan, ancaman, dan tantangan pelembagaan hukum Islam di Indonesia serta beberapa daerah yang memiliki aspirasi kuat untuk menerapkan shariah Islam, khususnya Aceh, maka ada prakondisi yang perlu disosialisasikan kepada masyarakat muslim. Prakondisi yang dimaksud adalah upaya untuk mencegah kejahatan yang dilakukan oleh umat Islam melalui langkah-langkah sebagai berikut:

1. Pencegahan melalui aspek akidah. Akidah yang kuat dapat membuat orang merasa diawasi oleh Tuhannya, sehingga ia mampu melakukan self control terhadap perbuatan yang dilakukannya.

2. Pencegahan dari aspek ibadah. Ibadah-ibadah yang diwajibkan oleh agama bila dilakukan dengan baik akan berdampak positif bagi pelakunya. Salat 
dapat mencegah perbuatan keji dan munkar. ${ }^{37}$ Dalam salat, seseorang harus meletakkan anggota badan yang paling terhormat, yakni wajahnya, ke lantai agar benih-benih kesombongan dapat tercabut dari jiwanya. Demikian pula zakat dapat dijadikan instrumen pembersih ${ }^{38}$ karena dapat membersihkan manusia dari kekikiran dan ketamakan. Realitas menunjukkan bahwa kejahatan lebih banyak dilakukan oleh mereka yang tidak begitu peduli dengan kualitas ibadahnya.

3. Pencegahan dari segi keadilan sosial. Dalam arti, setiap warga negara telah diberi kesempatan yang mudah untuk memenuhi kebutuhannya dengan cara yang halal dan tertutup dihadapannya kesempatan untuk berbuat yang tidak halal atau yang membuatnya tertarik dengan hal-hal yang tidak halal. Pencegahan seperti ini pernah dijadikan klausul tidak diterapkannya hukum potong tangan bagi pencuri ketika paceklik pada masa 'Umar bin Khattab.

4. Pencegahan melalui amar ma'ruf nabi munkar yang seharusnya menjadi budaya di kalangan masyarakat muslim karena hal ini merupakan titik sentral dari ajaran agama. Pelaksanaan amar ma'ruf nabi munkar secara rapi dan terarah, apalagi dilembagakan jabatan mubtasib secara resmi oleh negara, akan dapat menjamin ketentraman, keadilan, dan hal-hal kondusif lain yang diharapkan oleh seluruh masyarakat.

Prakondisi tersebut merupakan upaya awal untuk menguji situasi dan kondisi moral masyarakat muslim di Indonesia. Apabila prakondisi itu telah diciptakan, sementara kejahatan dan kerusakan moral tetap terjadi, maka tidak ada alasan untuk menolak pelembagaan hukum Islam. Pelembagaan dan penerapan hukum Islam dapat dipastikan akan meminimalisir tindak kejahatan yang terjadi. Hal ini terbukti bahwa pada zaman Nabi Muhammad saw hukuman zina hanya dilaksanakan satu kali karena pengakuan pelakunya dan ia meminta untuk dirajam. Ini berarti penerapan dan pelembagaan hukum Islam dapat dijadikan alternatif yang tepat untuk menekan angka kejahatan yang akhir-akhir ini semakin merebak, apalagi bila kita menyaksikan informasi tindak kriminal yang disiarkan oleh televisi seperti sergap di RCTI, buser di SCTV, patroli di INDOSIAR, dan lain-lain.

Setelah menciptakan prakondisi, maka upaya pelembagaan hukum Islam terlebih dahulu dilakukan hal-hal sebagai berikut: Pertama, melakukan pembaruan pola dan kurikulum pendidikan hukum secara sistematis dan terencana terhadap materi hukum Islam maupun hukum umum, sehingga sarjana hukum yang dihasilkannya berkualitas, produktif, responsif, dan antisipatif terhadap perkembangan sosial masyarakat. Kedua, mewujudkan integrasi kelembagaan antara Fakultas Syari'ah IAIN sebagai pembina hukum Islam dengan Fakultas Hukum di PTN sebagai pembina hukum umum. Upaya ini pada akhirnya akan menghilangkan perbedaan dalam trikotomi hukum di Indonesia yaitu Islam, Adat, dan Barat. Ketiga, menggalakkan dialog, seminar, dan forum-forum lainnya, antara para pakar hukum Islam dengan pakar 
hukum umum untuk menemukan kesamaan visi dan persepsi dalam rangka pembangunan hukum nasional.

Upaya-upaya tersebut pada akhirnya harus mendapatkan perhatian serius dari berbagai pihak yang memiliki kompetensi dalam bidang hukum seperti para pakar maupun orang-orang yang memiliki kepedulian terhadap pentingnya pelembagaan hukum Islam, termasuk di dalamnya pelembagaan hisbah, seperti para politisi dan tokoh-tokoh masyarakat. Jika tidak ada perhatian yang serius dan usaha yang konkrit maka upaya tersebut hanya akan menjadi sekedar wacana tanpa bentuk yang jelas.

Selain itu prospek pelembagaan hukum Islam di Indonesia, menurut Muhammad Daud Ali, dapat diterapkan melalui enam jalur sebagai berikut: ${ }^{39}$

\begin{tabular}{|c|c|c|}
\hline $\mathbf{N}$ & Jalur & Penerapannya di Indonesia \\
\hline 1 & Iman dan takwa & $\begin{array}{l}\text { Pemeluk agama Islam dapat } \\
\text { melaksanakan hukum Islam yang } \\
\text { merupakan bagian dan berasal dari } \\
\text { agama Islam dalam bidang ibadah. } \\
\text { Intensitas pelaksanaannya tergantung } \\
\text { kepada kualitas keimanan dan ketakwan } \\
\text { yang ada pada diri Muslim yang } \\
\text { bersangkutan. }\end{array}$ \\
\hline 2 & $\begin{array}{l}\text { Peraturan } \\
\text { Perundang- } \\
\text { Undangan }\end{array}$ & $\begin{array}{l}\text { Dalam berbagai peraturan perundang- } \\
\text { undangan telah ditunjuk hukum } \\
\text { perkawinan, hukum kewarisan, dan } \\
\text { hukum perwakafan sebagai hukum yang } \\
\text { berlaku bagi umat Islam. Jalur ini } \\
\text { dipergunakan dalam rangka penerapan } \\
\text { hukum Islam di bidang mu'amalah } \\
\text { seperti sanksi yang diberikan oleh } \\
\text { penyelenggara negara melalui Peradilan } \\
\text { Agama. Ketiga bidang hukum ini telah } \\
\text { dikumpulkan dalam satu buku yaitu } \\
\text { KHI yang telah menjadi hukum terapan } \\
\text { bagi Peradilan Agama di seluruh } \\
\text { Indonesia melalui Inpres no. } 1 \text { tahun } \\
\text { 1991 }\end{array}$ \\
\hline 3 & Pilihan Hukum & $\begin{array}{l}\text { Dengan melakukan perbuatan atau } \\
\text { transaksi tertentu di Bank Muamalat, } \\
\text { Bank Perkreditan Rakyat Syari'ah, dan } \\
\text { Asuransi Takaful, orang telah memilih } \\
\text { hukum atau syari'at Islam mengenai }\end{array}$ \\
\hline
\end{tabular}


Al-Fikra: Jurnal Ilmiah Keislaman, Vol. 3, No. 2, Juli-Desember 2004

\begin{tabular}{|c|c|c|}
\hline & & $\begin{array}{l}\text { perbuatan atau transaksi itu, sebab } \\
\text { semua perbuatan atau transaksi itu } \\
\text { dilakukan menurut hukum Islam }\end{array}$ \\
\hline 4 & $\begin{array}{l}\text { Badan Arbitrase } \\
\text { Muamalat } \\
\text { Indonesia } \\
\text { (BAMUI) }\end{array}$ & $\begin{array}{l}\text { Melalui BAMUI para pengusaha, } \\
\text { pedagang, dan industriawan atas } \\
\text { kesepakatan bersama dapat memilih } \\
\text { hukum Islam untuk menyelesaikan } \\
\text { sengketa mereka secara damai di luar } \\
\text { pengadilan }\end{array}$ \\
\hline 5 & $\begin{array}{l}\text { Melaksanakan } / \text { me } \\
\text { nerapkan hukum } \\
\text { Islam }\end{array}$ & $\begin{array}{l}\text { Hukum Islam dlaksanakan oleh } \\
\text { Lembaga Pusat } \\
\text { Obat/Kosmetika dan Menelitian } \\
\text { (LPPOM) yang didirikan oleh MUI. } \\
\text { Lembaga ini menentukan apakah suatu } \\
\text { produk obat-obatan, kosmetik, } \\
\text { makanan, dan minuman itu halal atau } \\
\text { haram dikonsumsi oleh umat Islam. }\end{array}$ \\
\hline 6 & $\begin{array}{l}\text { Pembinaan dan } \\
\text { Pembangunan } \\
\text { hukum nasional }\end{array}$ & $\begin{array}{l}\text { Melalui pembangunan hukum nasional } \\
\text { unsur-unsur (asas dan norma) hukum } \\
\text { Islam akan berlaku dan dilaksanakan } \\
\text { bukan hanya bagi dan oleh umat Islam, } \\
\text { tetapi juga oleh penduduk Indonesia, } \\
\text { terutama warga negara RI }\end{array}$ \\
\hline
\end{tabular}

\section{Jalur Penerapan Hukum Islam}

Dari keenam jalur tersebut, pelembagaan hisbah dapat dilakukan melalui jalur peraturan dan perundang-undangan yang pada akhirnya dapat menetapkan bisbah sebagi institusi resmi negara dalam bentuk perluasan yurisdiksi Peradilan Agama. Selain keenam jalur tersebut dapat juga ditempuh beberapa pilihan berikut ini:

\begin{tabular}{|l|l|}
\hline Perubahan Konstitusi & $\begin{array}{l}\text { Semua peraturan di bawah konstitusi } \\
\text { harus sesuai dan tidak boleh } \\
\text { bertentangan dengan hukum Islam. }\end{array}$ \\
\hline Mengubah Sistem Hukum Nasional & $\begin{array}{l}\text { Mengadakan perubahan besar-besaran } \\
\text { terhadap hukum substantif serta } \\
\text { menghidupkan jabatan al-qadi, al- } \\
\text { mubtasib, dan wali al-mazalim. }\end{array}$ \\
\hline Islamisasi Hukum Nasional & $\begin{array}{l}\text { Melakukan islamisasi terhadap hukum } \\
\text { privat yang meliputi kekeluargaan, } \\
\text { perkawinan, dan lain-lain, dan hukum } \\
\text { publik yang meliputi hukum pidana, } \\
\text { tata usaha negara, dan lain-lain. Selain } \\
\text { itu harus dipersiapkan aspek }\end{array}$ \\
\hline
\end{tabular}


Al-Fikra: Jurnal Ilmiah Keislaman, Vol. 3, No. 2, Juli-Desember 2004

\begin{tabular}{|c|c|}
\hline & $\begin{array}{l}\text { struktural yang meliputi rekrutmen, } \\
\text { kurikulum, tugas dan wewenang para } \\
\text { penyelenggara dan penegak hukum } \\
\text { yang dilengkapi dengan hukum acara } \\
\text { yang didasarkan pada hukum Islam. }\end{array}$ \\
\hline $\begin{array}{l}\text { Perluasan Kompetensi Peradilan } \\
\text { Agama. }\end{array}$ & $\begin{array}{l}\text { 1. Perkara perdata yang ada sekarang } \\
\text { perkawinan, kewarisan, dan wakaf } \\
\text { dapat ditambahkan hukum } \\
\text { ekonomi Islam yang meliputi } \\
\text { perjanjian, transaksi, dan lain-lain. } \\
\text { 2. Hukum pidana yang meliputi } \\
\text { hudud, qisas, dan ta'zir. } \\
\text { 3. Hukum acara peradilan Islam } \\
\text { misalnya hukum pembuktian. }\end{array}$ \\
\hline $\begin{array}{l}\text { Memasukkan Unsur/Konsep Hukum } \\
\text { Islam tertentu dalam Hukum } \\
\text { Nasional }\end{array}$ & $\begin{array}{l}\text { Klasifikasi tindak pidana (budud, } \\
\text { qisas\}, dan ta'zir), sanksi (jilid, rajam, } \\
\text { diyat, dan lain-lain), peran korban } \\
\text { berupa pemaafan dari korban dan } \\
\text { keluarga, tujuan hukum untuk } \\
\text { melindungi kepentingan pokok } \\
\text { manusia (maqasid shari'ab). }\end{array}$ \\
\hline $\begin{array}{l}\text { Optimalisasi Undang-Undang } \\
\text { Pemerintahan Daerah }\end{array}$ & \\
\hline
\end{tabular}

\section{Pilihan Pelembagaan Hukum Islam}

Demikianlah beberapa pilihan yang dapat dipikirkan bersama secara mendalam oleh berbagai pihak. Setiap pilihan tentu saja mengandung implikasi dan agenda untuk dipikirkan kembali. Faktor-faktor yang sangat berpengaruh bagi pilihan-pilihan tersebut antara lain faktor dukungan masyarakat (sosialkultural), kemenangan kekuatan politik Islam (sosial politik), tersedianya para pakar hukum dan shariah yang menggali konsep-konsep pelaksanaan hukum Islam sekaligus memecahkan problem-problem konseptual, penyusunan bukubuku dan literatur lain, serta pembahasan naskah-naskah akademis melalui seminar, lokakarya, dan lain-lain.

Oleh karena itu, diharapkan banyak orang yang mengetahui hukum Islam menjadi anggota DPR yang dengan fungsi legislatifnya dapat memberikan konstribusi besar dalam upaya menerapkan hukum Islam ini. Hal ini disebabkan hukum Islam, seperti hisbah, itu baru bisa diterapkan apabila telah menjadi hukum positif dalam negara Indonesia, seperti hukum perkawinan, kewarisan, dan wakaf. Dengan melihat fakta-fakta historis dan aplikasi penerapan hukum Islam di Indonesia, maka prospek pelembagaan hukum Islam akan semakin cerah. Bahkan Bustanul Arifin memprediksi bahwa 
Insya Allah, 100-200 tahun yang akan datang, bangsa Indonesia akan merasa bangga menyaksikan kenyataan bahwa di negara yang berdasarkan Pancasila dan UUD 1945, Peradilan Agama berkembang dengan subur. ${ }^{40}$

\section{Penutup}

Dari uraian-uraian tersebut dapat dipahami bahwa kehadiran hukum Islam dalam hukum nasional merupakan sub-sistem dari sistem hukum nasional. Munculnya beberapa undang-undang dan peraturan pemerintah ${ }^{41}$ telah menjadi bukti bahwa hukum Islam sebagai bagian tidak terpisahkan dari sistem hukum nasional. Kondisi ini menunjukkan kepada kita bahwa untuk melembagakan hukum Islam dalam sistem hukum nasional di Indonesia tidak semudah membalikkan telapak tangan, karena dalam pelembagaan ini banyak dijumpai hambatan dan ancaman yang harus dihadapi oleh hukum Islam. Namun dengan kekuatan yang dimiliki, ternyata peluang untuk melembagakan hukum Islam berhasil diraih oleh umat Islam, walaupun, masih dalam hukum kekeluargaan, seperti perkawinan, kewarisan, dan wakaf, bahkan belakangan ini sudah pula diraih pelembagaan hukum zakat dan haji. Produkproduk hukum ini dapat dijadikan indikator utama bahwa prospek pelembagaan hukum Islam di Indonesia akan semakin cerah untuk masa yang sangat panjang dan diprediksi akan semakin baik dan berkembang. Oleh karena itu, usaha pelembagaan hukum Islam dalam kehidupan berbangsa dan bernegara harus terus dilakukan tanpa mengenal henti, sehingga pada akhirnya seluruh aspek kehidupan muslim dilindungi oleh hukum agamanya.

Dengan demikian dapat dinyatakan di sini bahwa hukum Islam telah mendapatkan tempat di hati masyarakat Indonesia, sehingga mampu diadopsi dalam sistem hukum nasional. Namun bila dilihat dari hukum material yang dijadikan bahannya maka wewenang Peradilan Agama baru meliputi hukum perkawinan, kewarisan, dan perwakafan. Sementara aspek-aspek hukum yang lain seperti hisbah belum mendapatkan kesempatan untuk dilembagakan. Oleh karena itu, upaya pelembagaan hisbah di Indonesia menjadi lapangan studi yang penting untuk dilakukan.

Hal ini didasarkan pada realitas objektif bahwa mayoritas penduduk Indonesia adalah muslim, maka sudah menjadi suatu keharusan bila aspekaspek kehidupan bangsa ini dilindungi oleh hukum agama mayoritas penduduknya, walaupun bentuk negara ini bukan negara Islam. Untuk menerapkan hukum Islam tidak harus membentuk negara Islam, karena dalam sejarah tercatat bahwa Islam tidak pernah menentukan bentuk negara yang ideal. Bentuk negara ideal diserahkan kepada umat Islam sesuai dengan situasi dan kondisi dimana mereka hidup. Dengan dasar negara Pancasila dan UUD 1945 terbuka peluang bagi umat Islam untuk melembagakan hisbah. Persoalannya adalah apakah umat Islam mau dan mampu mempergunakan peluang ini? 
Untuk menjawab persoalan ini maka penelitian harus terus dilakukan oleh para sarjana, terutama Sarjana Hukum Islam (SHI), tentang konsep bisbah dan upaya pelembagaannya di Indonesia. Penelitian ini penting dilakukan dengan pertimbangan bahwa pada saat ini upaya serius yang dilakukan di negara-negara berpenduduk muslim, tak terkecuali Indonesia, adalah selain mengejar ketertinggalan dalam bidang ilmu pengetahuan dan teknologi, juga secara bertahap memperbarui hukum, yang sebagiannya masih merupakan peninggalan kolonial. Dalam upaya ini, para pakar, akademisi, dan praktisi hukum Islam dituntut untuk memberikan solusi agar tercipta hukum nasional yang bisa mengayomi segenap lapisan masyarakat dari berbagai tindakan yang merusak moral dan mengganggu kesejahteraan serta ketertiban umum mereka.

\section{Catatan Akhir:}

${ }^{1}$ Topik tentang pemenuhan kebutuhan-kebutuhan dasar dalam Islam telah mendapat perhatian dan tempat yang penting dalam fiqh dan literatur Islam lainnya di sepanjang sejarah kaum muslimin. Para fuqaba' secara aklamasi telah menyepakati bahwa fardu kifayah hukumnya bagi masyarakat muslim untuk memperhatikan kebutuhan-kebutuhan pokok orang miskin. Abu Muhammad 'Ali bin Hazm, al-Muballa,vol 6 (Beirut: al-Maktab al-Tijari, tt), 156, lihat juga, Abu Ishaq al-Shatibi, al-Munvafaqat fi Usul al-Shari'ah, 2 (Kairo: al-Maktabah al-Tijariyah al-Kubra, t.t), 177, 'Abd al-Salam al-'Abbadi, al-Milkiyyah fi al-Shari'ah al-Islamiyyah (Kairo: al-Maktabah al- Salafiyyah, 1349 H),163.

2 Munculnya kelompok pengajian Manajemen Qalbu yang dipimpin oleh KH. Abdullah Gymnastiar setiap hari Minggu pukul 16.00 WIB di Trans TV, Bedah Bisnis Syari'ah yang dipandu oleh Reza Syarif setiap hari Kamis pukul 05.00 WIB di RCTI merupakan salah satu bentuk penyadaran kepada kaum muslimin bahwa Islam itu dapat dijadikan pedoman dalam kehidupan.

3 Taufik Adnan Amal, Islam dan Tantangan Modernitas: Studi Atas Pemikiran Fazlur Rahman (Bandung: Mizan, 1994), 33.

4 Pendapat seputar masuknya Islam ke Nusantara terdapat perbedaan pendapat. Hasjmy dan disetujui oleh para ahli sejarah lainnya seperti Hamka, Abu Bakar Aceh, dan Muhammad Said menyatakan behwa Islam telah masuk ke Nusantara pada abad pertama Hijriyah (antara abad VII dan VIII Masehi). Sementara itu, para sejarawan Belanda seperti Snouck Hurgronye dan G.W.J. Drewes menyatakan bahwa Islam masuk ke Aceh sekitar abad ketujuh Hijriyah atau XIII Masehi. Kedua versi ini dapat dipahami bahwa Islam sebagai agama dakwah telah mesuk ke Aceh pada abad pertama melalui padagang Arab dan Gujarat. Sedangkan Islam eksis dengan kekuasaan terjadi pada abad XIII yang ditandai dengan berdirinya Kerajaan Islam Samudra Pasai. G.W.J. Drewes,"Pemahaman Baru Tentang Kedatangan Islam Di Indonesia," dalam, Islam di Asia Tenggara (Jakarta: LP3ES, 1989), 9. Lihat juga, Azyumardi Azra, Jaringan Ulama(Bandung: Mizan, 1993), 24-36. Hasjmy, Sejarah Kebudayaan Islam Di Indonesia (Jakarta: Bulan Bintang, 1990), 3-4.

${ }^{5}$ Ahmad Rofiq, Hukum Islam di Indonesia (Jakarta: Rajagrafindo Persada, 1995), 12.

6 Rachmat Djatnika,"Sosialisasi Hukum Islam di Indonesia", dalam, Abdurrahman Wahid, Konstribusi Pemikiran Islam di Indonesia (Bandung: Remaja Rosdakarya, 1991), 230.

${ }^{7}$ Sucipto,'Tinjauan Kritis Terhadap Pembangunan Hukum Indonesia" dalam, Analisis CSIS, No. 1, (Januari-Februari, 1993), 64. 
${ }^{8}$ Juhaya S. Praja, Hukum Islam, Pemikiran dan Praktek (Bandung: Remaja Rosdakarya, 1994), xi-xii.

${ }^{9}$ Redaksi Sinar Grafika, Amandemen UUD 1945 (Jakarta: Sinar Grafika, 1999), 16.

${ }^{10}$ Muhammad Daud Ali, "Kedudukan Dan Pelaksanaan Hukum Islam Dalam Negara Republik Indonesia," dalam, Hukum Islam Dalam Tatanan Masyarakat Indonesia (Jakarta: Logos, 1997), 45.

${ }^{11}$ Hartono Mardjono, Menegakean Syari'at Islam Dalam Konteks Keindonesiaan (Bandung: Mizan, 1997), 28. Lihat juga. Muchsin, Hukum Islam Dalam Perspektif dan Prospektif (Surabaya: Al-Ikhlas, 2003), 18.

12 Menurut Yusril Ihza Mahendra, pelaksanaan ajaran suatu agama yang pelaksanaannya memerlukan campur tangan kekuasaan dapat diatur dengan peraturan perundang-undangan. Inilah hakikat negara berdasarkan Pancasila dan UUD 1945, yang sering disebut "bukan negara agama dan bukan pula negara sekuler" itu. Negara tidak dapat mengintervensi hal-hal internal yang berhubungan dengan doktrin agama-agama. Tetapi, negara wajib memberikan bantuan dan pelayanan jika umat beragama membutuhkan peraturan perundang-undangan demi kelancaran dan ketertiban pelaksanaan ajaran agamanya. Hal ini bukanlah suatu intervensi, melainkan semata-mata bantuan dan pelayanan sesuai dengan kehendak umat beragama yang bersangkutan. Yusril Ihza Mahendra, Dinamika Tatanegara Indonesia Kompilasi Aktual Masalab Konstitusi Dewan Perwakilan dan Sistem Kepartaian, (Jakarta: Gema Insani Press, 1996), 119-120.

13 Muchsin, Hukum Islam Dalam Prespektif dan Prospektif (Surabaya: al-Ikhlas, 2003), $18-19$

${ }^{14}$ Setiap umat boleh mempunyai aturan-aturan pokok dan khusus sesuai dengan adat, susunan kehidupan, dan tingkat kemajuannya. Dalam ilmu figh siyasah, terdapat al-siyasah alwada'iyyah yaitu perundang-undangan yang dibuat oleh manusia yang bersumber kepada al-'urf, al-'adah, al-tajarib, dan al-awda' al-mawruthah. Hukum-hukum yang berasal dari sumber tersebut dapat menjadi bagian dari siyasah shar'iyyah apabila ada dalil penopang atau tidak bertentangan dengan shari'ah. Lihat, 'Abd al-Rah \{man Taj, al-Siyasah al-Shar'iyyah wa al-Figh alIslami (Mesir: Matba'at Dar al-Ta'lif, 1953), 8-11. Secara lebih rinci 'Abd al-Wahhab Khallaf menyatakan bahwa siyasah shar'iyyah merupakan ilmu yang membahas hukum-hukum yang mengatur urusan negara, berupa undang-undang dan peraturan-peraturan lain yang sesuai dengan usul al-din, sekalipun pada urusan yang diatur itu tidak ada dalil khusus (ayat al-Qur'an atau hadith). Objek pembahasan ilmu ini adalah peraturan dan perundang-undangan yang dibutuhkan suatu negara dan dibuat sesuai dengan dasar-dasar agama untuk memenuhi kemaslahatan manusia. Ilmu ini bertujuan untuk mengetahui kemampuan pemerintah mengatur urusan-urusan negara dan menjelaskan bahwa Islam menjamin siyasat yang adil dalam menjaga dan mewujudkan kemaslahatan pada masa dan negeri yang berbeda-beda. Lihat juga, 'Abd al-Wahhab Khallaf, al-Siyasab al-Shar'iyyah (Kairo: Dar al-Ansar, 1977$), 5$.

${ }^{15}$ Ichtijanto SA,Prospek Peradilan Agama Sebagai Peeradilan Negara Dalam Sistem Politik Hukum di Indonesia, dalam, Amrullah Ahmad, Dimensi Hukum Islam Dalam Sistem Hukum Nasional (Jakarta: Gema Insani Press, 1996), 178

16 Redaktur Sinar Grafika, Amendemen, 24.

${ }_{17}$ Muhsin, Hukum Islam, 29

18 Ibid., 30-31. 
${ }^{19}$ Freddy Rangkuti, Analisis SWOT Teknik Membedah Kasus Bisnis (Jakarta: Gramedia, 2000), 19 .

${ }^{20}$ Muin Salim, Konstitusionalisasi Hukum Islam di Indonesia (makalah), 3-5.

21 Al-Shatibi, al-Munafaqat, 3-4.

22 Ibid.

23 Djatnika,"Sosialisasi", 232.

24 Alamsyah Ratuperwiranegara, Kebidupan Agama Dalam Negara Pancasila, Abdullah Sukarta (penyunting) (Jakarta: departemen Agama, 1988), 38.

25 Hazairin, Demokrasi Pancasila (Jakarta: Rineka Cipta, 1990), 34.

26 Arifin, Pelembagaan, 36.

${ }^{27}$ Jimly ash-Shiddiqie,"Hukum Islam di Indonesia: Dilema Legislasi Hukum Agama di Negara Pancasila", dalam, Majalah Pesantren, No. 2, vol. VII, 1990, 13.

${ }_{28}$ Busthanul Arifin, Pelembagaan Hukum Islam di Indonesia: Akar, Sejarah, Hambatan, dan Prospeknya (Jakarta: Gema Insani Press, 1996), 33-34.

29 Zarkowi Soejoeti,'Diperlukan Pusat Pengkajian Hukum Islam Yang Berwibawa", dalam, Amrullah Ahmad, Dimensi Hukum Islam Dalam Hukum Nasional (Jakarta: Gema Insani Press, 1994), 256.

30 Ibid., 256.

31 Majalah Sabili, No. 2 tahun IX, 18 Juli 2001.

32 Majalab Forum Keadilan No. 7, 20 Mei 2001.

33 Ibid.

34 Ibid.

35 Sabili, 20 Mei 2001.

36 Teks lengkap undang-undang ini berikut penjelasannya dapat dilihat pada buku, Muhsin, Hukum Islam, 255-289.

${ }^{37}$ al-Qur'an, 29: 45.

38 Ibid., 9: 103.

39 Ali,"Kedudukan," 50.

40 Arifin, Pelembagaan, 88.

41 UU No. 14 tahun 1970 tentang Ketentuan-Ketentuan Pokok kekuasaan Kehakiman, UU No. 1 tahun 1974 tentang Perkawinan, PP No. 9 tahun 1975 tentang pelaksanaan UU No. 1 tahun 1974, PP No. 28 tahun 1977 tentang perwakafan tanah milik, UU No. 7 tahun 1989 tentang Peradilan Agama, Inpres No. 1 tahun 1991 tgl. 10 Juni 1991 tentang penyebarluasan Kompilasi Hukum Islam, UU No. 7 tahun 1992 tentang Perbankan, UU No. 17 tahun 1999 tentang pennyelenggaraan ibadah haji, UU No. 38 tahun 1999 pengelolaan zakat, UU. No 44 tahun 1999 tentang Penyelenggaraan Keistimewaan Provinsi DI Aceh, UU. No. 18 tahun 2001 tentang Otonomi Khusus Provinsi DI Aceh sebagai Provinsi Nangroe Aceh Darussalam. 